\title{
Squawk talk: commentary by birds in the Bayeux Tapestry?
}

\author{
GALER. OWEN-CROCKER
}

BORDER MOTIFS: SOURCES, TECHNIQUE, SIGNIFICANCE

It is well known that the design of the main register of the Bayeux Tapestry draws on the illuminated manuscript tradition both in general stylistic terms and in specific borrowing of scenes. The borders also, at times, draw on images from manuscripts, but they mostly derive from a long tradition of decorated textiles. The motif of pairs of creatures confronted and addorsed is first known from Mesopotamian art ${ }^{1}$ and was taken up in the woven silks widely exported from the Sassanian empire, centred on present-day Iran, which flourished from the third to the seventh centuries. The theme is typically manifested as heraldic-type creatures in roundels. Birds and bird-like creatures seem to have had benevolent significance according to eastern belief and typically include cocks, ducks and the mythical dog-bird, the senmurv. These motifs remained popular on medieval woven silks, but they were also used in different ways in western Europe: woven into or brocaded onto tablet woven bands which were a particularly northern art form, and reproduced in decorated manuscripts.

This is the ancestry of most parts of the borders of the Bayeux Tapestry. This embroidered frieze, which is over $70 \mathrm{~m}$ long, has upper and lower borders largely occupied by pairs of creatures: animals, birds and mythical winged beasts. When birds and animals appear on woven silks, they can be exact repeats because they are produced mechanically. The Tapestry takes up this traditional motif of birds and beasts, but with a diversity only partially explained by the fact that the creatures are embroidered rather than woven. The designer seems deliberately to cultivate variety and so we find a mixture of physiognomies, birds with long necks (fig. $1 a, g$ ) short necks (fig. 1b), or hardly any necks at all (figs. 1c,8); there are birds with curly wings (fig. $1 d$ ), bars on wings and tails (figs $1 e, 8$ ) and with feathers indicated by wavy lines (fig. $1 f$ ). Even within a pairing of confronted birds there is an avoidance of mirror-image repetition: wings, necks or feet occur in slightly different positions (fig. 1c), and though the pair are usually embroidered in the same colours, the shades may be

${ }^{1}$ M. Nockert, The Högom Find and other Migration Period Textiles and Costumes in Scandinavia, Archaeol. and Environment 9, Högom Find pt II (Umeå, Sweden,1991), 99. 
Gale Owen-Crocker
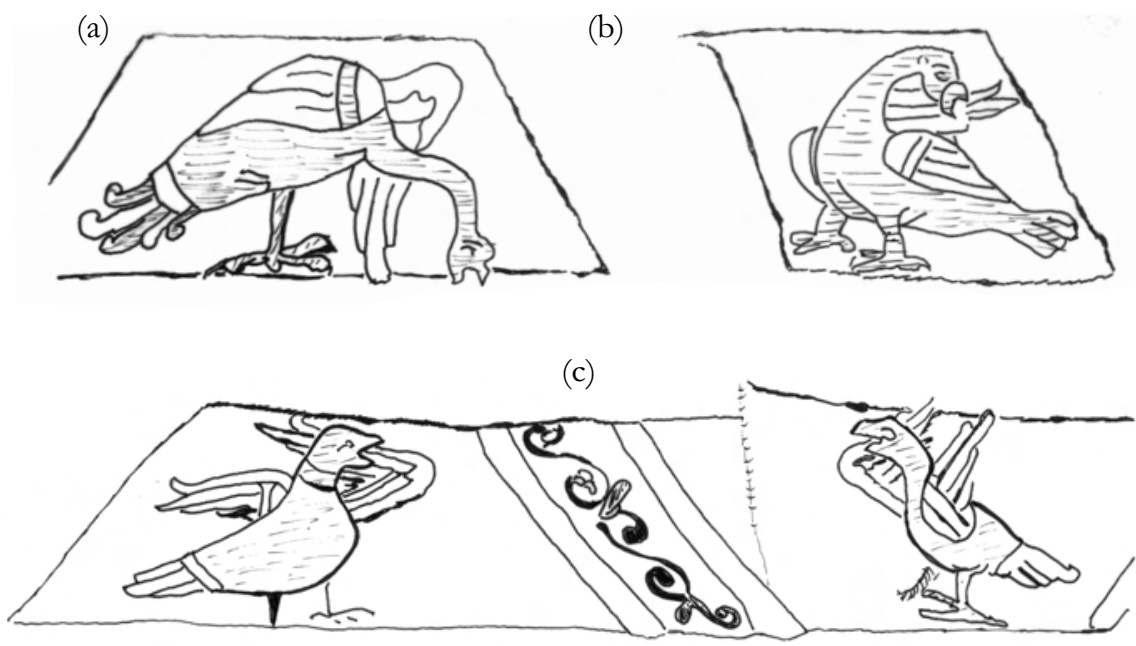

(d)

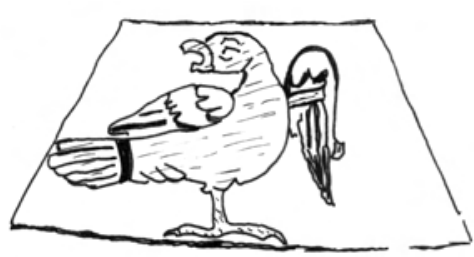

$(\mathrm{f})$

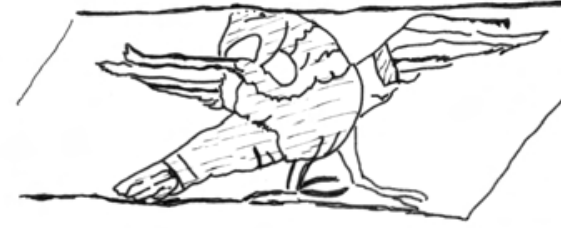

(h)

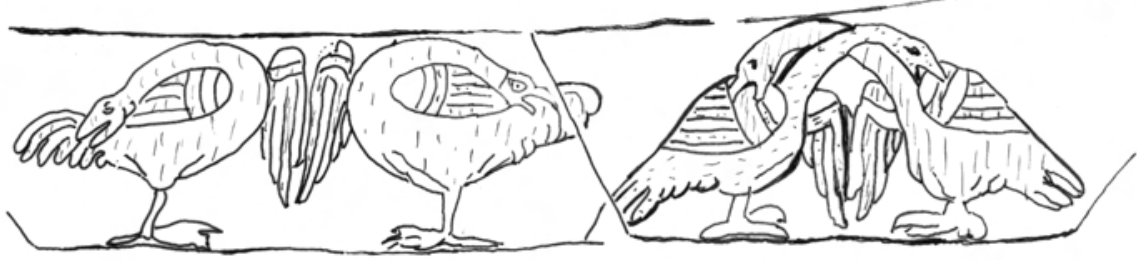

Figure 1

(g)

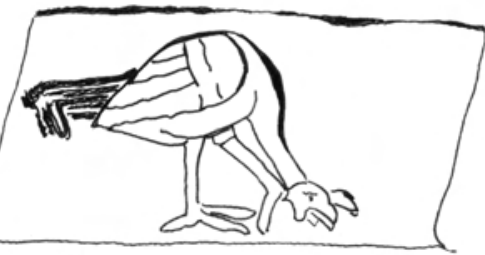

(i) 


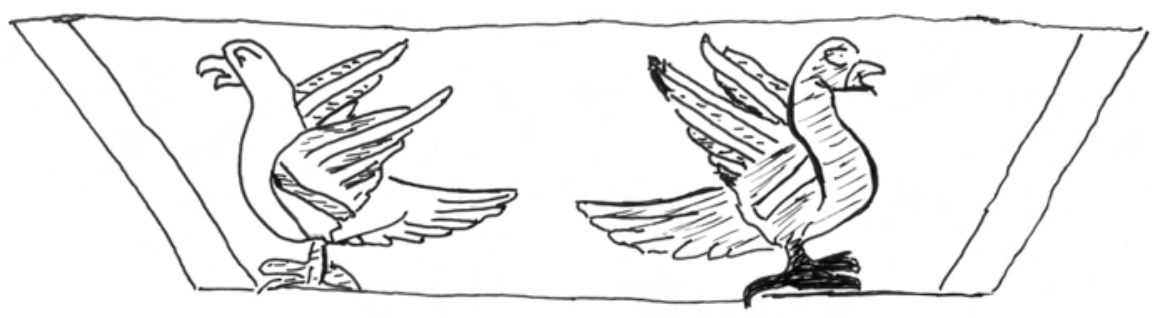

Figure 2

applied differently (figs. 1i, 2, 6a). Almost all the birds stand alone, even when they have a partner: there are very few cases of juxtaposed birds (fig. 1 h) and only one of stylized birds intertwined in the manner of earlier Anglo-Saxon decorative art (fig. 1i). The majority of the Bayeux birds have an individuality and apparent 'naturalism' which is unusual in early medieval textiles, indeed in early medieval art in general. (For detailed captions, see above, pp. vii-viii.)

The border birds are, on the whole, less formally posed than the border animals. A bird is basically symmetrical, unless it is sleeping or cleaning itself, but the wings of the Bayeux birds are often independent, giving the creatures expression, sometimes making it appear that they are gesturing. With their asymmetry, peering heads and prying beaks, the birds have an amusing and sometimes ironic anthropomorphism. They seem to have been deliberately given vitality, which is originally the inspiration of the artist, but it is achieved through the unique technique of the embroidery. Anyone who has seen the Tapestry in real life must be aware of its three-dimensional quality, of bright, thick wool against the plain linen background, an effect which is flattened and lost in any photograph, however good. Unlike the appearance of animals and birds on other textiles, which have been created by weaving, or by embroidering threads parallel to the weft, or by stitching in blocks of parallel stem stitches, the Tapestry's laid-and-couched stitching can be angled differently for different parts of a creature's anatomy, suggesting shape (pl. VII). Of vital importance is the Tapestry designer's adaptation of Canterbury techniques of manuscript illumination, such as can be found in the Old English illustrated Hexateuch, London, British Library, Cotton Claudius B. iv, ${ }^{2}$ whereby areas are filled with blocks of colour, with outlines and contours drawn strongly in ink. Translating this into stem-stitched outlines and contours, which can extend at any angle across the woven background and between blocks of laid-andcouched colour, the Tapestry gives the impression of curves, and of fluidity.

2 See The Old English Illustrated Hexateuch, ed. C. R. Dodwell and P. Clemoes, EEMF 18 (Copenhagen, 1974). 


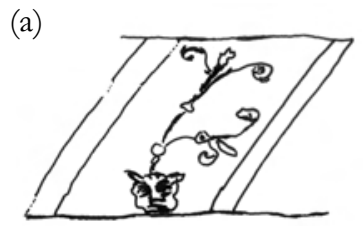

(b)

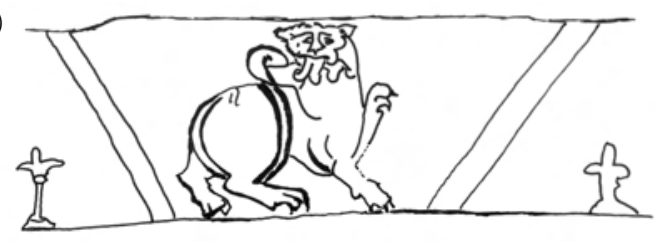

Figure 3

Commentators on the Tapestry disagree about whether the borders are simply decorative or whether they relate thematically to the main narrative. ${ }^{3}$ Significance is inevitably first sought in the little scenes acknowledged as illustrating Aesop's Fables and in the 'genre scenes' which are sometimes interpreted as fables, sometimes as scenes of medieval life. The following study will take a wide look at the Tapestry's birds, not forgetting the birds in fables and the hawks on the fists of Harold and his associates in the main register, but also focusing on the pairs of border creatures that are often overlooked. ${ }^{4}$

\section{BIRDS IN THE BAYEUX TAPESTRY}

I count 217 birds in the whole Tapestry, rising to 218 if the face at the foot of a spray of foliage is an eared owl (fig. $3 a$ ). Owls in medieval manuscripts often have a human look, even to the extent of having human ears. ${ }^{5}$ However, there are some full-face lions in the Tapestry borders which have a similar appearance (fig. 3b) so this may not be an owl, just a rather poor attempt to represent a full face, animal or human. Parts of the pillaging scene fill the main register below it. This section of the Tapestry is rather badly drawn and trivial in content; pos-

${ }^{3}$ For the former viewpoint, see C. Hicks, 'The Borders of the Bayeux Tapestry', England in the Eleventh Century: Proceedings of the 1990 Harlaxton Symposium, ed. C. Hicks, Harlaxton Med. Stud. 2 (Stamford, 1992), 251-65 and for the latter, in particular J. Bard McNulty, The Narrative Art of the Bayeux Tapestry Master (New York, 1989) and Visual Meaning in the Bayeux Tapestry: Problems and Solutions in Picturing History, Stud. in French Civilization 28 (Lewiston, 2003).

${ }^{4}$ I would like to acknowledge my debt to Brunsdon Yapp's zoological/ornithological studies of medieval art: B. Yapp, Birds in Medieval Manuscripts (London, 1981); 'Birds in Bestiaries: Medieval Knowledge of Nature', The Cambridge Review (1984), 183-90; and as W. Brunsdon Yapp, 'Animals in Medieval Art: the Bayeux Tapestry as an Example', JMH 13.1 (1987), $15-73$

5 See Yapp, Birds in Medieval Manuscripts, p. 35: 'the flat face, giving binocular vision, and eyes and mouth surrounded by a circular, oval or heart-shaped pattern of feathers, the facial disc, give the owl a somewhat human look, which may be emphasised by the hooked beak being drawn to resemble a nose'. Yapp adds (p. 37) 'A peculiarity of a few medieval owls is that they have mammalian, or even human, pinnae (external ears).' There is an example in The Luttrell Psalter (London, British Library, Add. 42130, English c. 1340), 177v, Yapp, ibid. fig. 22. In manuscripts owls are often used for 'drolleries'. 
sibly it was inserted to occupy space. ${ }^{6}$ The border 'owl' may be the result of similar workmanship. My count omits the border fantasy creatures with wings. These include dragons and winged lions; and hybrid creatures, the griffin which has an eagle's head and claws and a lion's body and back legs, combining the qualities of the lion, king of the beasts and the eagle, king of the sky; ${ }^{7}$ and the senmurv or dog-bird, a combination of dog and peacock which originated in Sassanian art and is manifested in the Tapestry as pairs of birds with mammalian legs and tails. ${ }^{8}$ It also omits the barbequed meats (Scenes 42-3; Wilson 46-7) ${ }^{9}$ which I cannot identify with any certainty, though they include whole creatures, smaller than the farm animals the Normans have pillaged, perhaps poultry.

The birds can be categorized as:

1 Pairs of border creatures, usually confronted but occasionally addorsed

2 'Unpaired' border creatures which may mark a change in design made in the course of the creative work. A creature may have had to be omitted because something from the main register had intruded on the border space after it had been measured and divided up for birds, beasts, bars and plants (pl. VIII a). Alternatively, if events depicted in the main register took up more space than expected, an 'extra' border creature might be inserted to occupy the marginal space (pl. VIIIb).

3 Birds in natural, rural situations: the 'bird-scaring' detail in a border agricultural scene (pl. VII) and a shorter scene in the lower border of a bird as predator chasing a hare (Scene 48, Wilson 54) which, like an earlier isolated scene of a hound chasing a hare (Scene 38; Wilson 41) is possibly a 'space-filler' (though the theme of hunting to kill is always relevant in this narrative); and two birds killed and carried by forward-moving predators beneath the Normans advancing to battle (fig. 4).

4 Birds in association with other creatures in unnatural, sometimes anthropomorphic situations, interpreted as fables. These include The Wolf and

${ }^{6}$ See G. R. Owen-Crocker, 'Brothers, Rivals and the Geometry of the Bayeux Tapestry', King Harold II and the Bayeux Tapestry, ed. G. R. Owen-Crocker (Woodbridge, 2005), pp. 109-23, at p. 120.

7 J. Rebold Benton, The Medieval Menagerie: Animals in the Art of the Middle Ages (New York, 1992), p. 22.

8 Hicks, 'The Borders', p. 260, n.19; J. Allgrove McDowell, 'Sassanian textiles', 5000 Years of Textiles, ed. J. Harris (London, 1993), pp. 68-70.

9 Reference is made to the scene numbers written on the sixteenth-century backing cloth (dated in G. Vial, 'The Bayeux Tapestry Embroidery and its Backing Strip', The Bayeux Tapestry: Embroidering the Facts of History, ed. P. Bouet, B. Levy and F. Neveux (Caen, 2004), pp. 111-16, at p. 115) which are reproduced in the fold-out versions of the Tapestry, La Tapisserie de Bayeux, Dessin de Roland Lefranc (Ville de Bayeux, undated) and La Tapisserie de Bayeux, Réalisation Edition Artaud Frères (Ville de Bayeux, undated); and to the plate numbers of the colour facsimile, D. M. Wilson, The Bayeux Tapestry (London, 1985). 


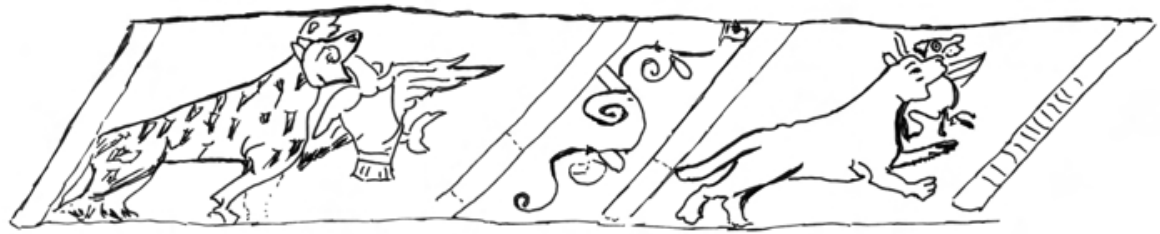

Figure 4

the Crane which is represented twice (Scenes 4, lower, 24, upper; Wilson 5, 27); The Fox and the Cheese which involves a confrontation between a fox and a crow, which occurs three times (Scenes 4, lower, 16, lower, 24 upper; Wilson 4, 18, 27-8; see fig. 7); and The Mouse, the Frog, and the Hawk (Scene 5, lower; Wilson 6).

5 Birds in the main register of the Tapestry: these include 'real' birds: the hawks on the hands of Harold, Guy and William (Scenes 2, 4, 8, 13, 14; Wilson 2, 4, 8, 9, 14, 15-16) and decorative birds: anguished-looking creatures as furniture finials (Scene 33; Wilson 32-3), ${ }^{10}$ and the terminal of a drinking horn, represented as the head of a bird, open beaked, demonstrating the loving detail lavished on the opening scenes of the Tapestry (fig. 5).

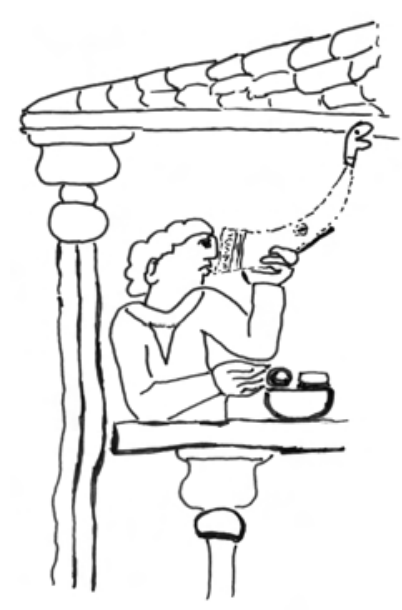

Figure 5

\section{BIRDS IN TRADITION}

In seeking to appreciate and evaluate the birds of the Tapestry it is important to recognize that this eleventh-century embroidery pre-dates the great period of popularity of bird illustration in medieval art. It was not until the thirteenth century that realistic depictions began to appear regularly. Birds had been used for ornamental purposes in earlier Anglo-Saxon art but they were usually 'generic' or fantastic creatures. The seventhcentury Lindisfarne Gospels (London, British Library, Cotton Nero D. iv) is an exception, in that it appears to use naturalistic cormorant-heads, but the geographical situation of its provenance, the Farne Islands, famed for bird-life today, provided unique inspiration. Ornamental birds do not

10 Discussed in detail in G. R. Owen-Crocker, 'Embroidered Wood: Animal-Headed Posts in the Bayeux Tapestry', Aedificia nova: Studies in Honor of Rosemary Cramp, ed. C. Karkov and H. Damico (Kalamazoo, MI, forthcoming, 2006). 


\section{Commentary by birds in the Bayeux Tapestry?}

appear to any great extent in tenth- and eleventh-century manuscript art, but of course wings are common: there are many illustrations of angels, often bearing wings that are asymmetrical and quite expressive.

The biblical tradition provided awareness of some specific birds, and biblical illustration offered models for certain types. The dove of the Holy Spirit was often depicted in $\operatorname{art}^{11}$ (though Yapp suggests the artists usually drew a pigeon) and the Noah story also featured a dove which brought back the olive branch as well as the raven which did not return to the ark. Apart from the Flood, biblical events involving various birds include the Creation and Adam naming the animals, in Genesis; and Revelation XIX.17-18: '[an angel] cried with a loud voice, saying to all the fowls [Vulgate volucres] that fly in the midst of heaven, Come and gather yourselves together... that ye may eat the flesh of kings, and . . of horses, and . . of all men'. ${ }^{12}$ The scene of Creation as depicted in the Junius Manuscript of Old English poetry (Oxford, Bodleian Library, Junius 11$)^{13}$ includes two birds with long necks and squawky beaks, which could be geese though they lack webbed feet, and a peacock with a rounded tail showing characteristic 'eye'-shaped markings and a crest of three feathers on its head. The peacock was also used symbolically to represent Christ and the resurrection and it was probably with this significance that it was depicted on King Æthelwulf's ring. ${ }^{14}$ In Gospel narrative St Peter's betrayal of Christ was marked by the cock crowing (Matthew XXVI.74-5; Mark XIV.71-2; Luke XXII.60-1), and a medieval artist would have associated the biblical narrative with the familiar domestic bird. Christians would also have been familiar with the beasts which had been used to represent three of the four evangelists since at least the fourth century. ${ }^{15}$ These included the eagle of St John which can be found in various degrees of realism in many Anglo-Saxon Gospel books.

Birds were also identified in non-biblical traditions. Modern scholars of medieval Europe will naturally think of relating the Tapestry creatures to the Bestiary, but again this is a tradition which largely post-dates the Tapestry. The original Greek Physiologus of the fourth or fifth century ${ }^{16}$ contained only thirteen real and mythical birds, and the Old English poetic Bestiary as it survives is even

11 Yapp, 'Animals in Medieval Art', p. 26. ${ }^{12}$ Yapp, Birds in Medieval Manuscripts, p. 104.

13 Poem, lines 206-10, bible, Genesis II:2-3; Anglo-Saxon Textual Illustration, ed. T. H. Ohlgren (Kalamazoo, MI, 1992), p. 533, 16.8.

14 D. M. Wilson, Anglo-Saxon Ornamental Metalwork 700-1000 in the British Museum (London, 1964), no. 31, pp. 22-9.

15 The Evangelist symbols derive jointly from Ezekiel I:5-14 and X:12-14 where the faces of man, lion, ox and eagle are attached to one body and Revelation IV:6-8; Yapp, Birds in Medieval Manuscripts, p. 26. Yapp notes (p. 27) the eagle aquila can also represent Christ or the resurrection but knows of no certain case (and does not give a source for the information).

${ }^{16}$ Yapp, Birds in Medieval Manuscripts, p. 10. 


\section{Gale Owen-Crocker}

more limited. Several Old English poems mention the 'Beasts of Battle' which include the eagle and the raven, and the 'Beasts' do on at least one occasion appear in the artistic tradition: a raven and a wolf are pictured consuming the dead in the Bury St Edmunds Psalter, Vatican City, Biblioteca Apostolica Vaticana, Reg. lat. 12, 87v. ${ }^{17}$ There was a scholarly tradition of listing birds in Latin-Old English glossaries and the author of the Old English poem The Seafarer exploits this enthusiasm for ornithological naming with a catalogue of sea birds.

These would be obvious sources to compare with the Tapestry birds, and we can find doves, peacocks and possibly the Bestiary's phoenix in potentially meaningful roles as I will show; but interrelationship is limited. Sadly my search of the Tapestry has not revealed a pelican in its piety or a cuckoo presaging sorrow. Nor are there any seabirds with webbed feet. There are a number of examples in the borders which might be eagles or ravens, but they do not obviously function as emblems of St John or the literary 'Beasts of Battle' waiting for carrion. At several points the birds in the upper border appear to take a keen interest in the armed knights, as they do in other matters throughout the Tapestry, but they disappear from the bottom border during the Battle of Hastings and are never seen pecking the dead, so this tradition, if the artist knew it, was evidently rejected, unless it occurred in the section now lost. Unlike later medieval artists the Tapestry designer does not exploit the biblical story of the swallow which struck Tobit blind with its dung, thus missing a wonderful opportunity on the theme of blinding, so important in relation to the death of King Harold Godwinesson and the memory of his father's involvement in the blinding of the Ætheling Alfred!

\section{IDENTIFICATION}

Modern birdwatchers identify birds by colour, size, the way they move, and by their general shape and attitude. The first three are not available to Tapestry scholars. The embroiderers were using a limited range of ten colours ${ }^{18}$ and they did not use them realistically. Proportions are unreliable, as creatures are not drawn to scale, particularly in the borders: we find camels smaller than neighbouring birds (Scene 13; Wilson 14). The limited width of the border generally precludes long legs and though we often find a bird with a long neck it usually lacks the leg length that would accompany it in a wading bird. Geese and swans, both well known in western Europe, have these proportions of long neck com-

17 Ohlgren, Anglo-Saxon Textual Illustration, p. 280, 3.32.

18 The most recent analysis extends the earlier identification of eight colours to 'ten main colours' achieved by dyeing with madder, woad or indigotin or combinations of woad and indigotin, plus 'the white shade of natural wool'; I. Bédat and B. Girault-Kurtzeman, 'The Technical Study of the Bayeux Tapestry', The Bayeux Tapestry, ed. Bouet, Levy and Neveux, pp. 83-109, at p. 91. 


\section{Commentary by birds in the Bayeux Tapestry?}

bined with short legs, which make them appear rather ungainly on land. It is possible that these species inspired some of the Bayeux birds. When a bird is depicted with long legs it is fitted into the narrow border space by the head being downwards (fig. 1g) or the neck bent (fig. 9).

Obviously birds in art cannot move but the Bayeux creatures seem especially animated; however, the movements they make are not designed to be anatomically accurate or characteristic of a species. Behind the Bayeux Tapestry creatures there were of course centuries of artistic expertise - manuscripts, metalwork, carvings - in which creatures and plants of various kinds had been intertwined and distorted for stylistic effect or to fit oddly shaped spaces. The surprising thing about the Bayeux birds, then, is not their inaccuracy but, given their time and context, their relative naturalism.

The conventional shorthand of medieval art is another bar to identification: the number of primary feathers in the wings of most birds is generally reduced to about five; $;^{19}$ the lack of webbed feet in the Tapestry might be another instance of convention. Even when a distinctive characteristic of a species is distinguishable, we can observe the depiction is conventional rather than zoological. The Tapestry, like medieval manuscripts, reduces the 'pin feathers' of the peacock to three when the correct number is about twenty-four (fig. 6). ${ }^{20}$ Sometimes the Tapestry artist omits or reduces features of a bird which are diagnostic to us and which, indeed, are found elsewhere in early medieval art. The distinctive 'eyes' on the train feathers of peacocks are present but not emphasized on the Tapestry birds. The crane characteristically has long stick-like legs, a 'bustle' of feathers and a red crown. These features are distinguishable in hunting scenes in two late Anglo-Saxon calendars (London, British Library, Cotton Julius A. vi, $7 \mathrm{v}$ and Tiberius B. v, $7 \mathrm{v}) .{ }^{21}$ We know that the bird in the lower border at Scene 4 of the Tapestry is a crane because the positions of the creatures in the scene make it clear that it illustrates the Aesop Fable of The Wolf and the Crane $e^{22}$ and it appears amongst other fables; but there is nothing anatomical to distinguish the bird as a crane except for the long neck which is perhaps appropriate to the fable. (The wolf has got a bone stuck in its throat and asks the crane to extract it; though it is the long bill rather than the neck of the crane that makes the operation possible.) At the second appearance of the fable the bird has just a few curly feathers which might represent the bustle (fig. 7). ${ }^{23}$

19 Yapp, 'Animals in Medieval Art', p. $20 . \quad{ }^{20}$ Ibid. p. 23.

21 See An Eleventh-century Anglo-Saxon Illustrated Miscellany, ed. P. McGurk, D. N. Dumville, M. R. Godden and A. Knock, EEMF 21 (Copenhagen, 1983), pl. IX, no. 76 (Julius) and p. 42 (Tiberius).

${ }^{22}$ H. Chefneux, 'Les fables dans le Tapisserie de Bayeux', Romania, 60 (1934), 1-35.

${ }^{23}$ Yapp says 'Here the jizz is even worse than in the first example except that the tail has a distinctly crane-like appearance'; 'Animals in Medieval Art', p. 38. 
(a)

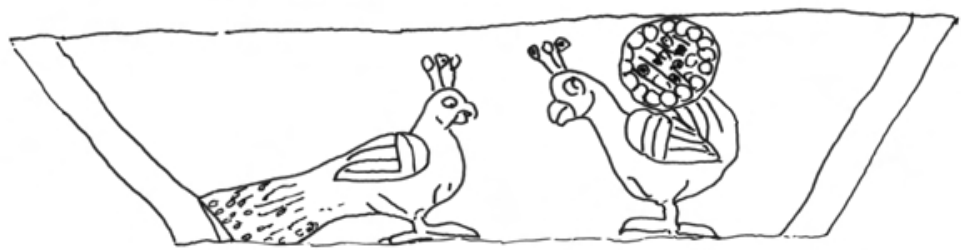

(b)

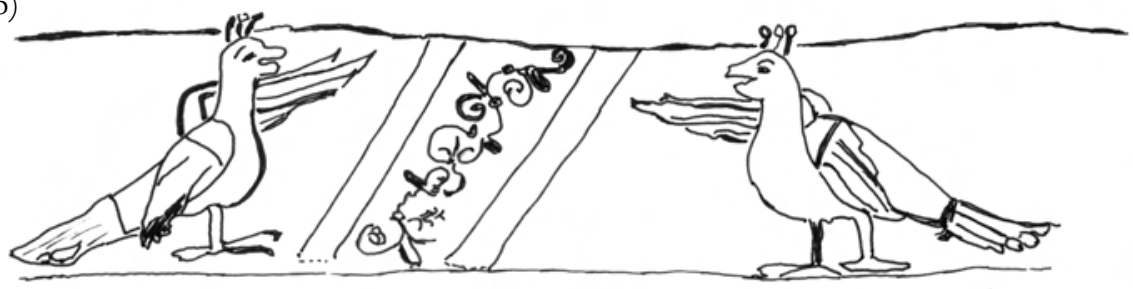

Figure 6

Similarly unrealistic and inconsistent is the bird in the fable of The Fox and the Cheese. According to different versions of the story, this bird ought to be either a crow or raven. Either way it should be black. Beneath Scene 4 it is red with green wings; beneath Scene 16 it is indeed dark; but at its third appearance, above Scene 24, it is red with yellow wings. The portrayal of this bird, symbolic of gullibility to flattery, does not help us to identify crows and ravens elsewhere in the borders.

Clearly then, even when we can identify an intended species of bird with a fair degree of certainty, we find some of the characteristics important to modern birdwatchers are omitted. In seeking to distinguish other birds in the Tapestry we are left largely with what Brunsdon Yapp tells us ornithologists call 'jizz', which he defines as 'shape and attitude'. I identify the following birds from a combination of 'jizz' and context, all of them either unique or uncommon in the Tapestry:

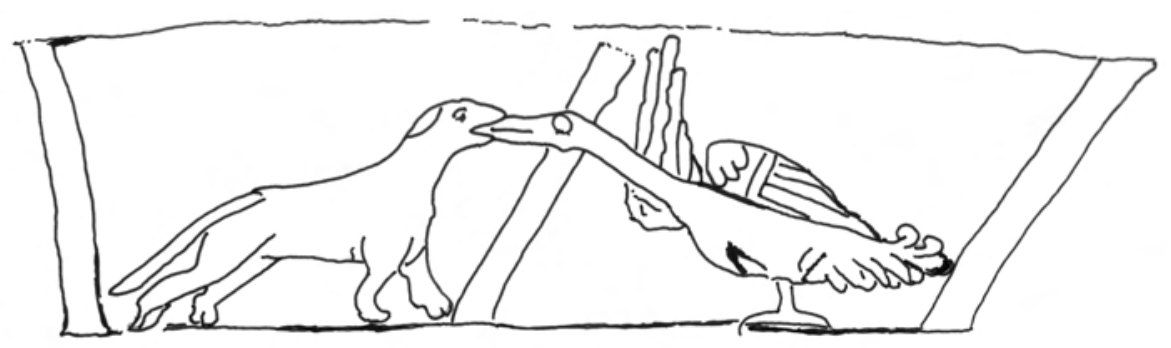

Figure 7 


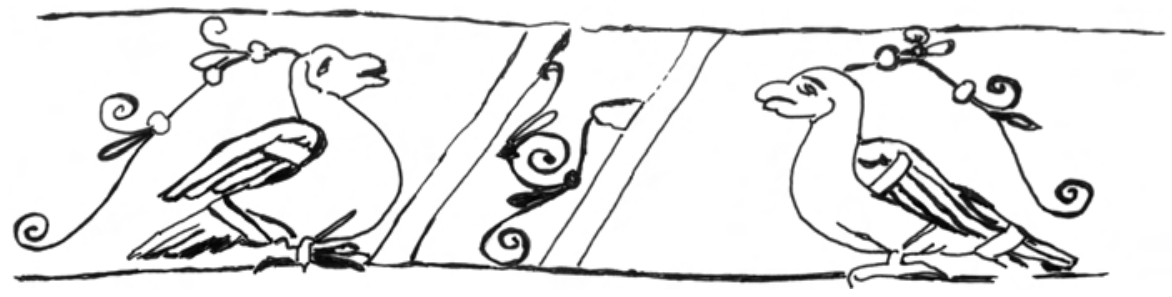

Figure 8

\section{Doves}

In a combination of the familiar and the iconographic, in the upper border of Scene 53 there is a pair of doves holding olive branches with fruit clearly visible (fig. 8). The identity of the birds is confirmed by the olive branch, carried by the dove in the biblical account of Noah (Genesis VIII.11). ${ }^{24}$ These profile doves are unlike any other birds in the borders, and so are particularly noticeable. They appear above the 'Mallefosse' incident in the Battle of Hastings, the most violent catastrophe of horses and riders to appear in the main register of the embroidery. A reference to peace at this point has to be ironic.

\section{Cocks}

There are other familiar birds in the crowing cocks which appear in the upper border as William's envoys ride urgently to extract Harold from his captor Guy (Scene 11; Wilson 12). Their crowing may reflect that the men carry a message, or perhaps it anticipates, like the cocks that crowed before St Peter's betrayal of Christ, that despite his bravado Guy will give up Harold to William, his rival and future enemy.

Brunsdon Yapp claims that a fox is carrying off a cock in the bottom border of Scene $51,{ }^{25}$ and that a larger bird with a red foot being carried off in the preceding box is a goose (fig. 4). The animals are probably both foxes, the embroidery on the left-hand one representing fur (rather than spots). Whatever species of birds and beasts are represented here, however, the border images clearly depict predators and prey, like the fable of The Wolf and the Goat that appears in the upper border at this point (Wilson 59-60). Significantly the main

24 The Anglo-Saxons may have used the dove divorced from specifically biblical context before - a version of King Edward the Confessor's seal shows a dove on the king's staff as an emblem of peace. This seal itself has been declared a forgery (see B. English, 'The Coronation of Harold in the Bayeux Tapestry', The Bayeux Tapestry, ed. Bouet, Levy and Neveux, pp. 347-81, at p. 366), but it may have copied an authentic image.

25 ' . . . the bird, which is white, can be recognised as a cock by its comb and wattle', Yapp, 'Animals in medieval art', p. 39. While I am willing to accept that this is a fox and cock, either as a fable of the Renard/Chanticleer type or as a scene from country life, I have to admit that I cannot identify Yapp's comb and wattle. 


\section{Gale Owen-Crocker}

frame shows Norman cavalry advancing inexorably towards the English infantry who stand in defensive formation.

There is also an inanimate cock in the form of a weather vane on Westminster Abbey (Scene 26; Wilson 29). ${ }^{26}$ The fact that a man is pictured in the act of installing the weathercock is a device indicating that the abbey was barely complete at the time of Edward the Confessor's burial there. It was consecrated on 28 December 1065 and his funeral took place on 5 January 1066.

\section{Peacocks}

A pair of peacocks in the upper border of Scene 14 (fig. 6a) have unusually marked differences in their positions, reflecting the attitudes of William and Harold beneath them. The birds are also dressed in the same colours as the human protagonists, ${ }^{27}$ and it seems likely that the peacocks are representing the men in some way. The chief characters in the Tapestry's narrative are here engaged in vehement discussion, ${ }^{28}$ Harold standing, animated, and William, though holding his sword point downwards (so evidently not aggressive), enthroned and pointing (Wilson 16-17). The peacock has been associated with pride since at least the later Middle Ages, ${ }^{29}$ and if this association was known

${ }^{26}$ McNulty, Visual Meaning in the Bayeux Tapestry, p. 59, while referring to the weathervane as 'the finishing touch' also suggests that the cock was included as an attribute of St Peter, to whom the abbey was dedicated, as stated in the inscription. This is an attractive suggestion, but the weathercock is not exclusive to St Peter's church. There is a weathercock above the church at Winchester depicted in the Benedictional of St Æthelwold, London, British Library, Add. 49598, 118v; see R. Deshman, The Benedictional of Æthelwold, Stud. in Manuscript Illumination 9 (Princeton, NJ, 1995), pl. 35.

27 I am grateful to Richard Crocker for this observation. William wears a dark blue-black cloak with yellow tunic and shoes. His stockings and the 'contour lines' on his garments are red; the peacock above and slightly to the right of him is predominantly dark blue-black, with yellow, blue-black and red wings. Its feet are yellow and its outline and contours are mainly red. Harold wears a green tunic with red contour lines under a red cloak, with yellow stockings. The peacock above him is predominantly green with green and yellow wings. Its feet and contour lines are mainly red.

28 Possibly about the continued holding of Harold's brother and nephew as hostage, as recorded by Eadmer (Eadmeri Historia Novorum in Anglia, et Opuscula Duo De Vita Sancti Anselmi et Quibusdam Miraculis Ejus, ed. M. Rule, RS 81 (London, 1884), pp. 6-8) and William of Poitiers (I.xiv, I.xli; The Gesta Guillelmi of William of Poitiers, ed. and trans. R. H. C. Davis and M. Chibnall (Oxford, 1998), pp. 20-2, 68-9); possibly about the legitimacy of the English succession as indicated by the inclusion of 'Ælfgyva' in the following scene and border nudes. (For the disputed identity of the female figure, see C. E. Karkov, 'Gendering the Battle? Male and Female in the Bayeux Tapestry', King Harold II and the Bayeux Tapestry, ed. G. R. OwenCrocker (forthcoming), n. 13.)

29 Bosworth-Toller quote 'proud as a po', citing The Political Songs of England, from the Reign of John to that of Edward II, ed. T. Wright, Camden Soc. 6 (1839), p. 159, line 15. Anglo-Saxon references are confined to glossing Latin pavo or comparing the peacock's anatomy to that of the mythical phoenix. See J. Bosworth and T. N. Toller, An Anglo-Saxon Dictionary (Oxford, 1898, repr. 1976), p. 772: páwa. 


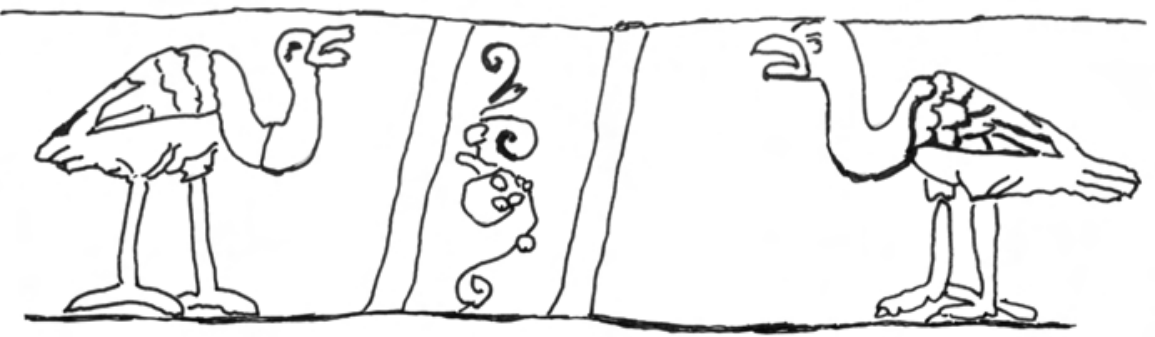

Figure 9

to the eleventh-century designer it might imply that both the disputants were obstinate. A second pair of peacocks (fig. 6b) stands beneath the Norman army as William exhorts them and they ride out in splendid array in Scene 51: MILITES PREPARENT. They appear to be gesturing with their wings, and, facing one another with open beaks, are perhaps commenting on the splendid display above them. These two birds, which are predominantly stitched in brownish-yellow, are surprisingly drab for peacocks. The implication is that the peacocks, well known as colourful exotics, are here outdone by the Norman knights. This may be a simple expression of admiration. It may be irony.

\section{Storks, cranes or herons}

A pair of long-legged birds with long, curving necks appears above the killing of King Harold's brothers at the Battle of Hastings (fig. 9) The creatures could be storks, cranes or herons, which were often confused in later medieval illustrations. They most resemble storks though their colour (predominantly brownish-yellow) is not appropriate. Long-legged birds are, as we have seen, unusual in the Tapestry borders, no doubt because of the shape of the available space, so these birds stand out and we must ask why. I suggest that just as cranes and storks were desirable prey for falconers, ${ }^{30}$ there being a lot of meat on them, so Harold's brothers Leofwine and Gyrth were an important kill for the Normans.

\section{Hawks}

Hawks are carried on the fist in several early scenes in the main register. ${ }^{31}$ The sport of falconry had been known in western Europe since the sixth century

30 See G. R. Owen-Crocker, 'Hawks and Horsetrappings: the Insignia of Rank', The Battle of Maldon AD 991, ed. D. Scragg, Oxford, 1991, pp. 220-37, at p. 221.

31 Hawks and falcons were both used for 'falconry', their different physical characteristics making them suitable for different terrains. The hawk has shorter wings than the falcon, and for this reason Yapp identifies Harold's bird as a hawk, probably a goshawk; 'Animals in Medieval Art', pp. 30-1. 


\section{Gale Owen-Crocker}

and artists were familiar with raptors, generally choosing, as here, to illustrate the short-winged hawk rather than the long-winged falcon. The hawks appear from Harold's journey to the English coast to the point where he ends up Duke William's prisoner in Normandy. The whole intention of this journey has been debated and the presence of the hawks features in the argument. It is uncertain whether the birds of prey are meant to indicate that Harold was setting off on a hunting trip and arrived in France unintentionally; ${ }^{32}$ or that the hawks (and hounds) were diplomatic gifts intended for Duke William on the occasion of a deliberate visit by Harold, ${ }^{33}$ either to negotiate the release of two members of the Godwine family held hostage by the Duke or to confirm to William that Edward the Confessor had nominated him as successor to the English throne. However, hawks on fists were used iconographically in both art and heroic poetry to indicate rank, ${ }^{34}$ and apart from any other significance they function that way here. As the hawks originally accompany Harold, are subsequently shared with Guy of Ponthieu, Harold's captor, and finally with Duke William, they act as markers of power and status, a commentary on Harold's changing fortunes.

\section{The 'bird-scaring' detail}

In the bottom border under Scene 10 (Wilson 10-11) a series of images depicts ploughing, sowing, harrowing and birds being scared away from the freshly sown field by a man with a catapult (detail, pl. VII). ${ }^{35}$ If the artist took this whole sequence from a lost calendar, ${ }^{36}$ then Yapp is probably correct in identifying the birds as rooks or other seed-eating birds of the countryside; ${ }^{37}$ but if the bird-scarer figure was copied from a similar one in the Old English

32 William of Malmesbury claims that Harold was blown accidentally to Pontieu, but states that he was on a fishing boat, not that he was going hunting (228.3-4); William of Malmesbury, Gesta Regum Anglorvm: The History of the English Kings, ed. and trans. R. A. B. Mynors, R. M. Thomson and M.Winterbottom, OMT, 2 vols. (Oxford, 1998-9) II, pp. 416-17.

33 See C. R. Dodwell, 'The Bayeux Tapestry and the French Secular Epic' (1966), repr. in The Study of the Bayeux Tapestry, ed. R. Gameson (Woodbridge, 1997), pp. 47-62, at p. 53, n. 33.

34 See Owen-Crocker, 'Hawks and Horsetrappings'.

35 I discuss this scene in detail in G. R. Owen-Crocker, 'Reading the Bayeux Tapestry through Canterbury Eyes', Festschrift for C. R. Hart, ed. A. P. Smyth and S. Keynes (Dublin, forthcoming).

36 Thus F. Wormald, 'Style and Design', The Bayeux Tapestry, ed. F. Stenton, (1st ed., London, 1957; 2nd ed. 1965), pp. 25-36, at pp. 27-8.

${ }^{37}$ In the Luttrell Psalter, 171r, the only known manuscript with a 'birdscarer' apart from the Old English illustrated Hexateuch, the birds follow the harrow and, according to Yapp, are 'clearly rooks' (Yapp, 'Animals in Medieval Art', p. 42). 'At the present time in England the most numerous [types of birds to follow a plough] would probably be rooks and gulls, but these are looking mostly for worms ... no doubt broadcast sowing attracted pigeons, house sparrows and finches as well' (pp. 41-2). 
Hexateuch, as has been supposed by several reputable scholars, ${ }^{38}$ then the artist must have known that in the context of this manuscript the birds were carrion eaters being scared away from carcases by Abraham. The artist in that case might have had a raven and eagle in mind. However, the birds are neither fierce-looking like carrion eaters, nor coloured to resemble rooks. Their plumage is in fact dissimilar, though they are embroidered in different combinations of the same colours, ${ }^{39}$ but it is not their physical characteristics that are important. Commentators disagree about whether this is what is known as a 'genre scene' (a depiction of everyday rural life), or a fable, and whether it is mere ornament or thematically significant. It is easy to suggest a significance but not easy to pin down the protagonists signified. Someone has prepared his ground carefully and wants to scare off anyone trying to steal his future crop. J. Bard McNulty thinks William is intending to scare off Harold from the throne he sees as rightfully his; ${ }^{40}$ but the scene comes beneath Guy of Ponthieu attempting to defy William's messengers. William might be trying to scare off Guy - he eventually succeeds; or at this point, Guy, having gone to the effort of taking Harold prisoner, might be determined to 'see off' William.

\section{Some doubtful identifications}

Some identifications have been made by other scholars which I include for the sake of completeness though I am not entirely convinced by them.

McNulty identified an ostrich in the bottom border at Scene 48 (Wilson 53) on the basis of the star which accompanies it, ${ }^{41}$ though the bird does not have very long legs. McNulty saw the ostrich as representing William as a symbol of military prowess, ${ }^{42}$ an interpretation which has been questioned even if the identification were to be accepted. ${ }^{43}$

38 Wormald, 'Style and Design', p. 32 and figs. 16, 17; D. Bernstein, The Mystery of the Bayeux Tapestry (London, 1986), p. 40, pls. 4, 7; C. Hart, 'The Canterbury Contribution to the Bayeux Tapestry', G. de Boe and F. Verhaege, ed., Art and Symbolism in Medieval Europe: Papers of the 'Medieval Europe Brugge 1997' Conference, 5, ed. G. de Boe and F. Verhaege (Zelik, 1997), pp. $7-15$, at p. 9, fig. 5.

39 Chefneux, 'Les fables dans le Tapisserie de Bayeux', pp. 18-21, interpreted this scene as the fable of The Man Sowing Flax, the Swallow and the Birds but neither of the birds is identifiable as a swallow.

40 McNulty, The Narrative Art of the Bayeux Tapestry Master, pp. 35-6.

41 The myth was that ostriches could not lay eggs unless they could see the Pleiades; McNulty, The Narrative Art of the Bayeux Tapestry Master, pp. 1-2. However, in McNulty, Visual Meaning in the Bayeux Tapestry, p. 20, the author cites a Renaissance source for this idea.

42 The point is developed in McNulty, Visual Meaning in the Bayeux Tapestry, pp. 19-21, where the ostrich as a potential example of proper Christian behaviour is related to William, and improper Christian behaviour to Harold.

43 W. Grape, The Bayeux Tapestry: Monument to a Norman Triumph, trans. D. Britt (Munich, 1994), pp. 41-2. 


\section{Gale Owen-Crocker}

A possible pair of phoenix is tentatively identified by Yapp, who makes a comparison with an illustration of a fenix in Tiberius B. v. ${ }^{44}$ The birds are brightly coloured and crested. ${ }^{45}$ They appear at Scene 18 (Wilson 21) in the main register on the mound beneath the castle of Dol which is under attack by the Normans. The phoenix should of course be unique, but it is typical of the Tapestry to draw creatures in pairs and it may be relevant to note that there is a group of five birds illustrating 'Lentisbelsinea where the red fowls burn if they are touched' at $79 \mathrm{r}$ of 'Tiberius B. $\mathrm{v}^{46} \mathrm{It}$ is the characteristic of the phoenix that it is consumed in flames. If Yapp is right, the Tapestry birds may confirm to us that the embroidery at the top left of the castle represents burning, ${ }^{47}$ perhaps a difficult concept to convey in embroidery and at its least successful here. Elsewhere the Tapestry artist incorporates men with blazing torches to indicate arson. ${ }^{48}$ However, the designer seems to have felt obliged to fill the mottes beneath his cities with symmetrical devices: Rennes has a pair of sheep, Dinan a pair of soldiers (arsonists) and Bayeux a pair of birds perched in a bush. Seen in this broader context the Dol birds are less likely to be significant.

In the same doubtful category I would include the possible owl (fig. 3a). If it is an owl, I do not know what, if anything, it might signify at this period. By the time of the Middle English poem The Owl and the Nightingale the owl has a moral and religious seriousness, but I would not force an interpretation here. It may be copied from a manuscript doodle.

\section{BORDER BIRDS IN RELATION TO THE MAIN REGISTER}

I have found it impossible to identify any other specific types. Some of them look somewhat like eagles, others like geese, but there is no obvious biblical symbolism or mythical significance to support the identification. The majority of border birds may be simply 'generic birds'; but that does not mean they are merely decorative. Often they echo what is going on in the main frame. As the Norman fleet completes its journey across the Channel (Scene 39; Wilson 43-4) both animals and birds in the upper border travel left to right, sharing the forward impetus of the invasion force, instead of confronting one another

${ }^{44}$ Fol. 82v, Marvels of the East (see McGurk et al., Miscellany); Yapp, 'Animals in Medieval Art', p. 31.

45 A simple crest is indicated by a line parallel to the outline. The jagged feathers appearing from behind the birds are wings.

${ }^{46}$ McGurk et al., Miscellany, p. 99. At pp. 99-100 McGurk and Knock identify these birds as cocks and a hen.

47 Yapp derives the suggestion from Wilson, The Bayeux Tapestry, p. 181.

48 In the following scene (Scene 19; Wilson 23) men are shown torching Dinan; there are no flames apart from those on the torches. Flames take the form of individual spikes under the cooking pot at Hastings and at the burning of an English house, where again, men with torches confirm that fire is being represented (Scene 47; Wilson 50-1). 


\section{Commentary by birds in the Bayeux Tapestry?}

in the usual way. In the bottom border (Scene 38; Wilson 42), outspread wings echo billowing sails. Preening birds over Normans in full war-gear (Scene 48; Wilson 52-3) may reflect the splendour of the warriors' appearance, but the preening, like the presence of the peacocks slightly further on, could be an ironic comment on human vanity. As Harold and a companion enter the church (Scene 3; Wilson 3), already bending their knees and making the sign of the cross, birds with crossed wings bow down in what seems to me a faintly comic imitation of this serious moment. ${ }^{49}$ The feast which follows is framed by border animals eating beneath and a border bird eating above. ${ }^{50}$ As Harold endures the embarrassment and humiliation of surrendering his sword to Count Guy of Ponthieu, the artist has tied the necks of the border birds in knots, graphically demonstrating the strangulation of Harold's prestige and ambition (fig. 10). The birds on the roof of Harold's regnal palace (Scene 33; Wilson 32-3) $)^{51}$ perhaps reflect a long tradition of augury. Beneath is a scene of panic and premonition. King Harold's previous assurance on his throne (Scene 30; Wilson 31) is shaken. His body language clearly reflects horror at the manifestation of Halley's Comet, shown in the upper border. ${ }^{52}$ Ghostly ships in the lower border suggest that the king thinks the comet presages invasion and the birds on the roof, the only creatures in the border at this point where manmade things otherwise intrude, chime with the anguished bird finials on Harold's throne, contributing to the impact of the scene.

Although birds are often used in the Tapestry to illustrate and comment on human situations, sometimes, conversely, it is as birds per se that we see them. As riders carry hawks in the main frame, border birds hide their heads (Scene 2; Wilson 2, lower border, heads downwards, Scene 8; Wilson 8-9, upper border, heads in wings). This is not natural behaviour in birds (not even for ostriches), but these birds are trapped in their border compartments, they cannot fly away, so they try to conceal themselves; their fear reminds us that though to the men who carry them the hawks are prestigious possessions, to the birds they will hunt they mean death. Death, specifically Harold's death in the carnage of the Battle of Hastings, which occupies more space in the

49 For a different reading of these birds, see H. E. J. Cowdrey, 'Towards an Interpretation of the Bayeux Tapestry' (1988), repr. in Study, ed. Gameson, pp. 93-110, at p. 99 and developed in 'King Harold II and the Bayeux Tapestry: a Critical Introduction', King Harold II and the Bayeux Tapestry, ed. G. R. Owen-Crocker, pp. 1-15, at p. 4.

${ }^{50}$ Only the left hand bird of the pair has something in its beak. The beak of its partner is open but empty.

51 Yapp, 'Animals in Medieval Art', p. 32. Yapp cannot identify them but suggests they might be pigeons or doves in a dovecote because of their position; alternatively owls or ravens as harbingers of doom. The suggestion of ravens is attributed to John Cherry.

${ }^{52}$ It is a historical fact that the comet appeared in the spring of 1066. I. W. Walker, Harold the Last Anglo-Saxon King (Stroud, 1997), p. 143. 


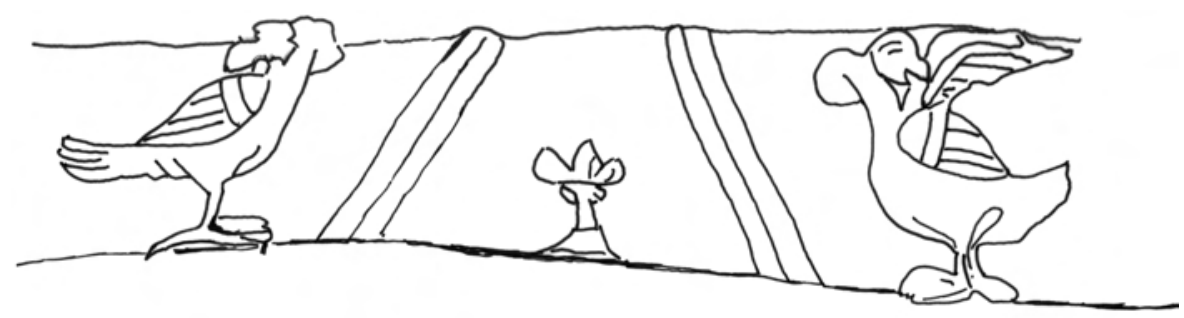

Figure 10

Tapestry than any other single event, is always to be the end to the story of the man who carries the hawk to Normandy. Men build Westminster Abbey (Scene 26; Wilson 29). A bird pecks it. The Abbey is the most splendid building in the Tapestry, blessed by the hand of God; but to birds it is merely a habitat. The birds' irreverence for what humans hold most sacred is amusing.

Commentators on the minor registers of the Tapestry, the borders, debate whether the embroidery contains a subversive subtext, questioning whether, while overtly telling the story from a Norman point-of-view, it also encapsulates the judgements of the defeated English on the predicaments and actions of the main protagonists. I will not comment here on possible political or moral judgements in the Tapestry; but I will say that a study of the border birds reveals a voice or voices different in tone from the main narrative. Like the court fool, the border artist seems to have licence to point out the vanity of human splendour, and to provide some light relief around the most serious and far reaching political event in England's history. Above all, the border birds with their craning necks, open beaks and expressive, asymmetric wings, appear to take an interest in the events of the main register, whether dialogue (Scene 49; Wilson 54-5), misadventure (Scene 17; Wilson 19-20) or combat, both trivial (Scene 45; Wilson 49) and mortal (Scene 55; Wilson 67-8). In this respect they are the most immediate audience of the main frame of the Tapestry. They variously express curiosity, horror, fear, admiration, imitation and indifference to achievements, and they sometimes diverge from the serious business with a witticism or an idiosyncratic reaction.

Visitors to the Tapestry cannot be unaware of the multinational comments as the public file past it. Spreading a reproduction before students and colleagues always gains a response, usually verbal. The audience reaction is subjective, amused, fascinated, delighted, horrified, just like the feathered watchers in the border. We are the birds; the birds are us. ${ }^{53}$

53 A version of this paper was read at the 39th International Congress on Medieval Studies, Kalamazoo, at a session in honour of Professor Donald Scragg, an enthusiastic birdwatcher. I am grateful to the British Academy for an Overseas Travel Grant. 